\title{
Safety assessment of cerium oxide nanoparticles: Combined repeated-dose toxicity with reproductive/developmental toxicity screening and biodistribution in rats
}

Jinsoo Lee

Korea Institute of Toxicology

Ji-Seong Jeong

Korea Institute of Toxicology

Sang Yun Kim

Korea Institute of Toxicology

Seung-Jin Lee

Korea Institute of Toxicology

Young-Jun Shin

Korea Institute of Toxicology

Wan-Jung Im

Korea Institute of Toxicology

Sung-Hwan Kim

Korea Institute of Toxicology

Kwangsik Park

Dongduk Women's University

Eun Ju Jeong

Korea Institute of Toxicology

\section{Sang-Yoon Nam}

Chungbuk National University College of Veterinary Medicine

Wook-Joon Yu ( $\nabla$ yuwj@kitox.re.kr)

Korea Institute of Toxicology

\section{Research}

Keywords: Cerium oxide nanoparticles, nanotoxicity, safety assessment, biodistribution

Posted Date: December 19th, 2019

DOI: https://doi.org/10.21203/rs.2.19340/v1 
License: (c) (i) This work is licensed under a Creative Commons Attribution 4.0 International License. Read Full License 


\section{Abstract}

Background Cerium oxide nanoparticles ( $\mathrm{CeO} 2 \mathrm{NPs}$ ) are widely used in various commercial applications because of their characteristic properties. $\mathrm{CeO} 2 \mathrm{NPs}$ can be easily exposed to humans in real life, but the safety assessment of $\mathrm{CeO} 2 \mathrm{NPs}$ has not been fully investigated. Therefore, in this study, we conducted a combined repeated-dose and reproductive/developmental toxicity screening study to investigate the potential effects on general health hazards, including reproductive/developmental functions, after repeated $\mathrm{CeO} 2 \mathrm{NPs}$ oral exposure. In addition, tissues from parental animals and their pups were collected to analyze the internal accumulation of cerium. $\mathrm{CeO} 2 \mathrm{NPs}$ were orally administered to SpragueDawley rats at doses of $0,100,300$ and $1000 \mathrm{mg} / \mathrm{kg}$ during their pre-mating, mating, gestation and early lactation periods.

Results In the general systemic and reproductive/developmental examinations, no marked toxicities were observed in any of in-life and terminal observation parameters in this study. In the biodistribution analysis, cerium was not detected in either parental or pup tissues (blood, liver, lungs and kidneys).

Conclusion Repeated oral exposure of $\mathrm{CeO} 2$ NPs did not induce marked toxicities affecting general systemic and reproductive/developmental functions up to the dose level of $1000 \mathrm{mg} / \mathrm{kg}$ and the $\mathrm{CeO} 2$ NPs were not systemically absorbed in parental animals or their pups. This result could be used to risk assessment for human, and additional toxicity studies with $\mathrm{CeO} 2$ NPs will be necessary considering various physicochemical properties and exposure probabilities of this nanoparticles.

\section{Introduction}

Nanomaterial development and research have precipitously increased recently, and engineered nanorelated items are continuously introduced to the market.[1] Cerium oxide nanoparticles $\left(\mathrm{CeO}_{2} \mathrm{NPs}\right)$ are one of the 13 priority listed representative manufactured nanomaterials to undergo assessments of the environmental safety and human health implications established by the Organization for Economic Cooperation and Development (OECD) Working Party on Manufactured Nanomaterials. [2] $\mathrm{CeO}_{2} \mathrm{NPs}_{\text {have }}$ been reported to have redox activity,[3] and their characteristic properties are used in a wide range of industrial areas, including UV-absorbing compounds in sunscreens, solid oxide fuel cells, catalytic convertors for removing toxic gases and diesel fuel catalysts.[4, 5, 6, 7] Extensive usage of $\mathrm{CeO}_{2} \mathrm{NPs}$ in various areas has raised human health concerns because of occupational and environmental exposure. However, the potential adverse effects of $\mathrm{CeO}_{2} \mathrm{NPs}$ have not been widely investigated thus far.

Recent publications have suggested that $\mathrm{CeO}_{2} \mathrm{NPs}$ are able to cause environmental toxicity and health problems. $\mathrm{CeO}_{2} \mathrm{NPs}$ exposure in cyanobacterial and green alga was found to induce cytotoxicity through cell wall and membrane disruption.[8] In addition, cytotoxicity was also observed in human lung epithelial cells (BEAS-2B) after $\mathrm{CeO}_{2}$ NPs exposure through increased reactive oxygen species.[9] In experimental animal studies, acute inhalation exposure of rats to $\mathrm{CeO}_{2}$ NPs induced cytotoxicity via oxidative stress in the lungs, and these effects were considered able to aggravate chronic inflammation.[10] Another study 
showed that exposure of rats to a single intravenous infusion of $\mathrm{CeO}_{2} \mathrm{NPs}$ led to body weight gain impairment, increased spleen weight and hepatic granulomas.[11] Moreover, these study results showed that $\mathrm{CeO}_{2} \mathrm{NPs}$ were able to be retained in internal organs, such as the spleen, liver and bone marrow. Consequently, these results support concerns about the adverse effects of long-term exposure to $\mathrm{CeO}_{2}$ NPs in humans and the environment.

Nevertheless, the potential adverse effects of repeated $\mathrm{CeO}_{2}$ NPs exposure have not been thoroughly investigated. In particular, developmental and reproductive toxicity studies with $\mathrm{CeO}_{2} \mathrm{NPs}$ have rarely been conducted. In this regard, the current study was conducted to assess the potential general systemic effects as well as developmental and reproductive effects after repeated $\mathrm{CeO}_{2} \mathrm{NPs}$ oral exposure based on an OECD guideline for testing of chemicals.[12] In addition, we collected maternal samples (blood, liver, lungs and kidneys) and F1 pup samples (blood, liver, lungs and kidneys) to analyze the internal systemic distribution of $\mathrm{CeO}_{2} \mathrm{NPs}$ after repeated oral exposure. Therefore, in this study, $\mathrm{CeO}_{2} \mathrm{NPs}$ were orally administered to Sprague-Dawley (SD) rats at doses of $0,100,300$ and $1000 \mathrm{mg} / \mathrm{kg}$ from premating to lactation periods, and then the $\mathrm{CeO}_{2} \mathrm{NPs}$-induced potential effects on general systemic, developmental and reproductive functions as well as the internal biodistribution of $\mathrm{CeO}_{2} \mathrm{NPs}$ were observed.

\section{Materials And Methods}

The current study was conducted in accordance with the OECD Good Laboratory Practice (GLP) regulations.[13] The study design was conducted in general accordance with OECD testing guideline 422, namely, "Combined repeated-dose toxicity study with the reproductive/developmental toxicity screening test".[12] The experimental phase of this study was conducted in 2015, and animal experiments were approved by Institutional Animal Care and Use Committee (IACUC) in accordance with the Animal Protection Act and the Guide for the Care and Use of Laboratory Animals.[14]

$\mathrm{CeO}_{2} \mathrm{NPs}$ and Nanoparticle Characterization

$\mathrm{CeO}_{2}$ NPs (CAS No. 1306-38-3) were obtained from Sigma-Aldrich (USA). The primary size and shape of $\mathrm{CeO}_{2} \mathrm{NPs}$ were characterized by transmission electron microscopy (TEM, JEM-2100F, JEOL, Japan). The mean particle size of at least $100 \mathrm{CeO}_{2}$ NPs was analyzed using a DigitalMicrograph image analyzer program (Gatan, Inc., USA). The purity of the particles was analyzed using energy-dispersive X-ray (EDX) (TEM equipped with a silicon drift detector, Oxford Instruments, UK). The particle hydrodynamic diameter and zeta potentials in vehicle $(10 \mathrm{mg} / \mathrm{ml}$ concentration) were characterized with ELS-8000 (Otsuka Electronics, Japan) using the dynamic light scattering (DLS) method. $\mathrm{CeO}_{2} \mathrm{NPs}$ in deionized water were identically sonicated by a Vibra-Cell ${ }^{\circledR}$ Model VC 505 sonifier (Sonics \& Materials, USA) as dose formulation preparation for oral gavage administration.

Animals and Maintenance 
Specific pathogen free naïve male and female SD rats (7 weeks of age) were obtained from Orient Bio, Inc. (Republic of Korea). Animals were housed as 2 (or one) animal(s) per stainless-steel cage (255W $\times$ $465 \mathrm{~L} \times 200 \mathrm{H} \mathrm{mm}^{3}$ ). Pregnant and lactating dams were housed individually in a poly-sulfone cage (260W $\times 420 \mathrm{~L} \times 180 \mathrm{H} \mathrm{mm}^{3}$ ) with sterilized Aspen animal bedding (Bio Lab, Republic of Korea) during the study period. The animal room was controlled environmental conditions as described previously,[15] with a temperature range of $22 \pm 3{ }^{\circ} \mathrm{C}$, a relative humidity range of $50 \pm 20 \%$, a 12 hours light-dark cycle and a ventilation range of 10-20 air changes per hour. The water was irradiated by UV light and filtered prior to provide ad libitum. The sterilized commercial rodent feed (PMI Nutrition International, USA) was also provided ad libitum. All animals received an acclimation period of 5 days to become accustomed to the laboratory environment. Then, healthy animals with adequate body weight increase and exhibiting no clinical signs were used in this study.

\section{Dose Selection and Experimental Group}

In the previous results of a preliminary study with $\mathrm{CeO}_{2} \mathrm{NPs}$ in SD rats (5 animals/sex/group) were used to select the dose levels of this study (data not shown). Animals were daily dosed $\mathrm{CeO}_{2} \mathrm{NPs}$ with 100 , 300 and $1000 \mathrm{mg} / \mathrm{kg}$ dose levels for two weeks prior to mating, and dosing was continued through final sacrifice in males (total 28 days) and through gestation day (GD) 15 in females (total of at least 29 days). In a preliminary study, there was no test item-related changes in all examined parameters at any doses tested. Therefore, $1000 \mathrm{mg} / \mathrm{kg}$, which is the limit dose level, was determined to the high dose, and 300 and $100 \mathrm{mg} / \mathrm{kg}$ were determined to the intermediate and low doses. Vehicle control animals were administered deionized water. $\mathrm{CeO}_{2} \mathrm{NPs}$ were diluted in deionized water and sonicated by the Vibra-Cell ${ }^{\circ}$ sonifier with a $13 \mathrm{~mm}$ probe at $25 \%$ amplitude for $8 \mathrm{~min}$. Dose formulations were mixed by a stirrer during the dosing, and dosing volume was $10 \mathrm{ml} / \mathrm{kg}$.

Twelve male and twelve female SD rats were divided to each of the groups to have a similar mean body weight using the Pristima system (Xybion Medical System Co., USA). $\mathrm{CeO}_{2} \mathrm{NPs}$ were daily administered by oral gavage in a volume of $10 \mathrm{~mL}$ on each animals. Males were administered during a 2-week premating period and during mating and up to the final sacrifice in males (total of 38 days). Females were administered during a 2-week premating period and during mating, gestation and up to lactation day (LD) 4 (total of at least 41 days).

In-life Observations

Clinical examinations including mortality and general clinical signs were examined twice daily. In addition, detailed clinical signs were examined once weekly during the study period. Animal body weights were measured twice weekly during the pre-mating and mating periods, on days $0,7,14$ and 20 of gestation, and on days 0 and 4 of lactation. Food consumption was also measured in the same days except for the mating and was calculated as $\mathrm{g} /$ animal/day. During mating, males and females were mated on a one-to-one basis for a period of up to 2 weeks. Mating was confirmed by the presence of sperm in the vaginal smear and/or the vaginal plug, and this was considered GD 0. Based on these 
mating results, the number of days the animals were confirmed to mate (precoital time) and fertilityrelated data, including mating, fertility, fecundity and pregnancy index, were calculated. Functional observations of animals, including sensory function tests (tail pinch, approach and touch response, pupillary reflex and acoustic startle response), grip strength and motor activity, were conducted with 6 animals/sex/group before necropsy. The progress and completion of parturition was monitored twice daily, including signs of parturition, premature delivery, abortion, and prolonged or difficult parturition. Pregnant females were allowed to access their litters, and then the gestation duration, number of dead and live pups, runts, sexing of live pups, live pup body weight and pup external abnormalities were recorded. After parturition, pup mortality and general clinical signs were examined once daily. Based on the parturition and pup mortality results, the delivery index (\% of dams with live pups among pregnant dams) and viability index (\% of survival pups on post-natal day 4 after birth) were calculated. Pup individual body weight and sex were recorded on post-natal day (PND) 0 and 4, and these data were reported for each litter.

\section{Terminal Observations}

All surviving males on the day after final dosing and females on LD 5 were humanely sacrificed with isoflurane. Blood for clinical pathology were collected from the caudal vena cava from 5 randomly selected animals/sex/group. Animals for blood collection were fasted approximately 16 hours (overnight) prior to sacrifice. Blood for hematology was placed into tubes containing potassium salt of ethylenediaminetetraacetic acid (EDTA) and then analyzed with an ADVIA2120i hematology analyzer (Siemens, Germany) for the following parameters: total red blood cell count (RBC), mean corpuscular volume (MCV), hemoglobin ( $\mathrm{HGB})$, hematocrit (HCT), mean corpuscular hemoglobin concentration $(\mathrm{MCHC})$, mean corpuscular hemoglobin $(\mathrm{MCH})$, platelet count $(\mathrm{PLT})$, reticulocyte count, total white blood cell count (WBC) and WBC differential count (absolute and relative counts of neutrophils [NEU], lymphocytes [LYM], monocytes [MON], basophils [BAS] and eosinophils [EOS]). Blood for coagulation was put into tubes containing 3.2\% sodium citrate and centrifuged (approximately 3,000 rpm, $10 \mathrm{~min}$, at room temperature) to obtain plasma. A coagulation test was conducted with an ACL 9000 coagulation analyzer (Instrumentation Laboratory, Italy) for the following parameters: activated partial thromboplastin time (APTT) and prothrombin time (PT). Blood samples for clinical chemistry were placed into tubes without anticoagulant and kept at room temperature for a minimum of $90 \mathrm{~min}$ and then centrifuged (approximately $3000 \mathrm{rpm}, 10 \mathrm{~min}$, at room temperature) to obtain serum. Clinical chemistry analysis was conducted with a Toshiba 200 FR NEO chemistry analyzer (Toshiba Co., Japan) for the following parameters: glucose (GLU), alanine aminotransferase (ALT), gamma glutamyl transpeptidase (GGT), aspartate aminotransferase (AST), total protein (TP), albumin (ALB), alkaline phosphatase (ALP), total cholesterol (TCHO), triglyceride (TG), albumin/globulin ratio (A/G), total bilirubin (TBIL), blood urea nitrogen (BUN), creatinine (CREA), phospholipid (PL), creatine phosphokinase (CK), sodium ( $\mathrm{Na})$, inorganic phosphorus (IP), calcium (Ca), potassium (K) and chloride $(\mathrm{Cl})$. After blood collection for clinical pathology, all animals were subjected to macroscopic observations, and the following organs were examined and preserved in $10 \%$ neutral buffered formalin or an appropriate fixative for histopathology: ovaries, testes, uterus with cervix, brain, stomach, ileum, duodenum, jejunum, colon, 
cecum, rectum, liver, kidneys, adrenal glands, spinal cord (cervical, thoracic, lumbar), prostate, epididymides, seminal vesicles with coagulation glands, thyroid with parathyroid glands, trachea, lungs with bronchi, mesenteric lymph nodes, mandibular lymph nodes, urinary bladder, femur with marrow, sciatic nerve, spleen, heart, thymus and abnormal lesions. All reproductive organs and the other organs from 5 animals per sex in each group were further processed to slides and stained with hematoxylin and eosin for histopathological examinations. Kidneys were also examined in the low- and intermediate-dose groups to further investigate the treatment-related changes. All male reproductive organs (testes, epididymides, seminal vesicles with coagulation glands and prostate) were weighed, and the following organs were weighed from 5 animals per sex in each group: liver, kidneys brain, pituitary gland, heart, thymus, spleen, ovaries, adrenal glands, lungs and uterus with cervix. Paired reproductive organs were weighed separately.

Tissue Collection and Cerium Analysis

Parental animal tissues (blood, liver, lungs and kidneys) and pup tissues (blood, liver, lungs and kidneys) were collected and weighed (approximately $200 \mathrm{mg}$ ) for cerium content analysis. Pup tissues were collected from at least 5 individual pups and pooled by litter. All collected tissues were stored in a deep freezer (approximately $-80^{\circ} \mathrm{C}$ ) until analysis. Cerium content analysis was conducted according to our previous study.[16] Briefly, thawed tissues were digested in a solution of $1 \mathrm{ml} 30 \% \mathrm{H}_{2} \mathrm{O}_{2}$ and $7 \mathrm{ml} 70 \%$ $\mathrm{HNO}_{3}$ with a microwave digestion system (Milestone, Italy). After wet digestion, the tissue concentrations of cerium were analyzed with an inductively coupled plasma atomic emission spectroscopy (ICP-AES) equipped with an Ultima 2 apparatus (Horiba Jobin, France).

Statistical Analysis

Statistical analyses were conducted based on the general statistical method used in this types of toxicology study and our previous study.[17] Statistical analysis was performed using the Pristima System or Statistical Analysis Systems (SAS Institute, USA), and the level of significance was taken when $p<0.05$ or $p<0.01$. Litter data were statistically evaluated using the statistical unit as a litter. Pup body weight was analyzed using one-way analysis of covariance (ANCOVA), and the litter size was used as the covariate.

\section{Results}

\section{Physicochemical Properties of $\mathrm{CeO}_{2} \mathrm{NPs}$}

The physicochemical properties of $\mathrm{CeO}_{2} \mathrm{NPs}$, including analyses of primary size, shape, purity and hydrodynamic size with zeta potential, are summarized in Table 1 . The average primary size of the $\mathrm{CeO}_{2}$ NPs was $14.2 \pm 5.03 \mathrm{~nm}$, and the majority of the $\mathrm{CeO}_{2} \mathrm{NPs}$ had a polyhedral shape with a purity of $100 \%$. The hydrodynamic size of the $\mathrm{CeO}_{2} \mathrm{NPs}$ was $76.3 \mathrm{~nm}$, and the zeta potential of the $\mathrm{CeO}_{2} \mathrm{NPs}$ in deionized water was $47.37 \mathrm{mV}$. 


\section{General Systemic Observations}

All animals survived to the scheduled sacrifice. Furthermore, observations of animals during the study period did not reveal any differences in clinical examinations among the treatment and control groups (data not shown).

Body weights during the study period are presented in Figure 1. There were no treatment-related changes in body weight or weight gain during the study. Food consumption during the study period is presented in Table 2. In male rats of the $300 \mathrm{mg} / \mathrm{kg}$ dose group, food consumption during the pre-mating day 1-4 was significantly lower $(0.93 \%$ of control) than in vehicle control animals.

In functional observations including sensory function tests (tail pinch, approach and touch response, pupillary reflex and acoustic startle response), grip strength and motor activity, there were no treatmentrelated changes during the study (data not shown).

In macroscopic observations, there were no treatment-related changes among the treatment and control animals (data not shown). Hematology results are presented in Table 3. In female rats of the $100 \mathrm{mg} / \mathrm{kg}$ dose group, the PT value was significantly higher (1.14-fold over control) than the respective level in the vehicle control animals. Clinical chemistry results are presented in Table 4. In male rats of the 1000 $\mathrm{mg} / \mathrm{kg}$ dose group, the GGT value was significantly higher (2.24-fold over control) than the respective level in the vehicle control animals. Other hematology and clinical chemistry values for the $\mathrm{CeO}_{2} \mathrm{NPs}$ treated animals were comparable to those of the vehicle control animals. Organ weights are presented in Tables 5 and 6 . There were no treatment-related changes in organ weights among the treatment and control animals.

Histopathological examination results are presented in Table 7. In male rats of the $1000 \mathrm{mg} / \mathrm{kg}$ dose group, an increased incidence of tubular basophilia in kidneys was observed.

\section{Developmental and Reproductive Observations}

Fertility results with precoital time are presented in Table 8 . There were no treatment-related changes in fertility results with precoital time. Reproductive and littering findings are presented in Table 9 . There were no treatment-related changes in reproductive and littering finding parameters during the gestation and lactation periods. In general clinical signs and external examination of F1 pups at necropsy, there were no treatment-related changes among the treatment and control animals (data not shown). F1 pup body weights are presented in Table 10. An increase in F1 male and female pup covariate-adjusted body weights (up to 1.11-fold over control) during the post-natal period (PND 0 and 4) was observed at 1000 $\mathrm{mg} / \mathrm{kg}$.

\section{Tissue Distribution of Cerium}

Tissue distribution analysis of cerium in parental and pup tissues revealed that $\mathrm{CeO}_{2} \mathrm{NPs}$ were not detected in almost all of the samples (data not shown). 


\section{Discussion And Conclusion}

$\mathrm{CeO}_{2} \mathrm{NPs}$ have been used in a wide range of industrial areas as a consequence of their characteristic properties. Indeed, they are used as a diesel fuel additive in Europe and are increasingly being employed as a catalyst in the automotive industry.[18,19] The increasing numbers of $\mathrm{CeO}_{2} \mathrm{NPs}$ used are expected to cause direct or indirect exposure in humans. However, their potential toxicological effects in human health are not well investigated. An in vitro study with $\mathrm{CeO}_{2} \mathrm{NPs}$ showed that they did not induce genotoxicities, including DNA and chromosomal damage, in human lens epithelial cells.[20] However, other in vitro studies imply the opposite results with respect to $\mathrm{CeO}_{2} \mathrm{NPs}$ toxicity. $\mathrm{CeO}_{2} \mathrm{NPs}$ exposure in human lung cancer cells yielded elevated oxidative stress and cell membrane damage.[21] In addition, $\mathrm{CeO}_{2}$ NPs exposure in human hepatocellular carcinoma SMMC-7721 cells induced damage and apoptosis via oxidative stress and the activation of MAPK signaling pathways.[22]

In vivo studies, such as acute oral gavage toxicity studies with $\mathrm{CeO}_{2} \mathrm{NPs}(30 \mathrm{~nm} ; 100$ and $5000 \mathrm{mg} / \mathrm{kg}$ ) in rats revealed that $\mathrm{CeO}_{2} \mathrm{NPs}$ did not have overt toxicities.[23] Another acute oral gavage exposure study of $\mathrm{CeO}_{2} \mathrm{NPs}$ ( $<25 \mathrm{~nm} ; 30$ and $300 \mathrm{mg} / \mathrm{kg}$ ) in rats reported that no significant toxicities were observed with respect to general clinical signs, clinical pathology parameters and histopathological examinations. [16] Repeated-dose oral gavage exposure of mice to $\mathrm{CeO}_{2} \mathrm{NPs}$ ( $3-5 \mathrm{~nm}$; weekly $0.5 \mathrm{mg} / \mathrm{kg}$ for 2 or 5 weeks) did not induce overt toxicities.[24]. Conversely, another repeated-dose oral gavage exposure study with $\mathrm{CeO}_{2} \mathrm{NPs}$ ( $<25 \mathrm{~nm} ; 30,300$ and $600 \mathrm{mg} / \mathrm{kg}$ for 28 days) in rats revealed that prolonged exposure to high concentrations has the potential to cause biochemical alterations, genetic damage and histological changes in the liver, spleen and brain.[25] In addition, single oral gavage exposure to $\mathrm{CeO}_{2} \mathrm{NPs}(4 \pm 1 \mathrm{~nm}$; $0.14 \mathrm{mg}$ to $2.57 \mathrm{mg} / \mathrm{kg}$ based on the representative animal weight) induced the disruption of microvascular smooth muscle signaling.[26] These inconsistent and insufficient toxicity results obtained with $\mathrm{CeO}_{2} \mathrm{NPs}$ indicate the necessity of standard toxicity studies that are acceptable by the regulatory authorities of various countries.

Combined repeated-dose toxicity with reproductive/developmental toxicity screening tests are required by OECD test guidelines for testing chemicals that are reviewed in light of scientific progress by the various regulatory authorities.[12] This toxicity study is needed for industrial chemicals with a production or import level of more than 10 tonnage per year according to the European Registration, Evaluation, Authorisation and Restriction of Chemicals (EU REACH) legislation.[27] This study design is able to assess various developmental and reproductive toxicity endpoints as well as general toxicity endpoints in subacute toxicity studies. Thus far, since controversial toxicity results have been obtained with $\mathrm{CeO}_{2} \mathrm{NPs}$ in previous in vitro and in vivo studies, the combined repeated-dose toxicity with reproductive/developmental toxicity screening test could be considered one of the most appropriate toxicity studies to evaluate the potential effects of $\mathrm{CeO}_{2} \mathrm{NPs}$ on general functions as well as developmental and reproductive functions. In addition, we also analyzed the internal systemic distribution of $\mathrm{CeO}_{2} \mathrm{NPs}$ in major organs (blood, liver, lungs and kidneys) of parental animals and their pups after repeated oral exposure. 
In general systemic evaluations after repeated $\mathrm{CeO}_{2} \mathrm{NPs}$ oral exposure, no $\mathrm{CeO}_{2} \mathrm{NPs}$-related dead or moribund animals were observed during the study period. Although food consumption was decreased during the pre-mating day 1-4 with statistical significance in $300 \mathrm{mg} / \mathrm{kg}$ dose group males, this finding was considered to be incidental since it was transient and did not have a dose-response. As for hematology, the significantly increased PT in $100 \mathrm{mg} / \mathrm{kg}$ dose-group females was considered to be incidental since it did not have a dose-response. Regarding clinical chemistry, a statistically significant increase in GGT in $1000 \mathrm{mg} / \mathrm{kg}$ dose-group males was also considered to be incidental since there were no correlated changes in organ weights and histopathological examinations. In the histopathological examinations, the increased incidence of tubular basophilia in the kidneys in $1000 \mathrm{mg} / \mathrm{kg}$ dose-group males was considered to be incidental since it also occurred sporadically in normal animals, did not have an obvious dose-response and yield no correlated clinical chemistry changes. In addition, there were no toxicologically significant $\mathrm{CeO}_{2} \mathrm{NPs}$-related changes in other examinations for general systemic effects.

In developmental and reproductive observations after repeated $\mathrm{CeO}_{2} \mathrm{NPs}$ oral exposure, there were no $\mathrm{CeO}_{2}$ NPs-related changes in any of the parameters except the body weights of the F1 pups. The covariate-adjusted body weights of the pups increased in both males and females during PND 0 and 4 at the $1000 \mathrm{mg} / \mathrm{kg}$. A change in pup growth compared with that of the concurrent control is one of the endpoints that can be indicates toxicity in a reproductive toxicity study.[28] It may be secondarily influenced by gestation length, maternal nutritional status and litter size.[29, 30] However, there were no concurrent changes in maternal body weight, litter size or gestation length in this study. It has also been reported that test substances with endocrine modes of action cause increased pup body weights. However, these endocrine effects were not clear in this study since there were no concurrent mode of action-related changes, including estrus cycle abnormalities and histopathological changes in reproductive organs.[31] In addition, biodistribution results indicated that $\mathrm{CeO}_{2} \mathrm{NPs}$ were not systemically observed in parental animals or their pups. Therefore, an increased pup body weight was not considered treatment-related, although the mechanism of $\mathrm{CeO}_{2} \mathrm{NPs}$ induced changes in the body weight of pups is not clear. Additional endpoint evaluations with an extended postnatal period was considered necessary to clearly elucidate the potential toxicological effects of $\mathrm{CeO}_{2} \mathrm{NPs}$ on the development of pups.

A biodistribution analysis after $\mathrm{CeO}_{2} \mathrm{NPs}$ exposure has been conducted in a few previous studies. Singleand 28-day repeated inhalation exposure to $\mathrm{CeO}_{2} \mathrm{NPs}(<5000,40$ and 5-10 nm; 55.00, 19.95 and $10.79 \mathrm{mg} / \mathrm{m}^{3}$ ) resulted in their distributed to the lungs, liver, kidneys, spleen, brain, testes and epididymides [32]. Hirst el al. [24] also reported that $\mathrm{CeO}_{2} \mathrm{NPs}(3-5 \mathrm{~nm}$; weekly $0.5 \mathrm{mg} / \mathrm{kg}$ for 2 or 5 weeks) were deposited in the spleen, liver, lungs and kidneys after intravenous and intraperitoneal administration. However, $\mathrm{CeO}_{2} \mathrm{NPs}$ were not considered to be deposited in internal organs after oral exposure. Most of the orally exposed $\mathrm{CeO}_{2} \mathrm{NPs}$ were excreted through feces within 24 hours. Other oral exposure studies with $\mathrm{CeO}_{2} \mathrm{NPs}(<25 \mathrm{~nm} ; 30$ and $300 \mathrm{mg} / \mathrm{kg}$ for 1 day and $6.6 \mathrm{~nm} ; 1 \mathrm{mg} / \mathrm{animal}$ for 1 day) suggested that they could hardly be absorbed in the gastrointestinal tract, and most of the orally exposed $\mathrm{CeO}_{2}$ NPs were excreted in feces within a few days.[16, 33] Our results also confirmed these 
previous studies showing that $\mathrm{CeO}_{2} \mathrm{NPs}$ were not deposited in parental internal organs after repeated oral exposure. In addition, we confirmed that $\mathrm{CeO}_{2} \mathrm{NPs}$ did not accumulate in the internal organs of the pups.

A lack of marked toxicity of $\mathrm{CeO}_{2} \mathrm{NPs}$ was observed in this study, but this finding does not mean that $\mathrm{CeO}_{2} \mathrm{NPs}$ are safe for humans and the environment. The toxicity of nanoparticles can be changed depending on their physicochemical properties, such as particle size, chemical composition and surface structure.[34] In fact, size-dependent toxicity and internal distribution differences of nanoparticles have been reported in previous studies. [35, 36,37] Furthermore, nanoparticles exposure in humans and the environment can occur through various exposure routes and scenarios considering the wide range of $\mathrm{CeO}_{2} \mathrm{NPs}$ application. $[18,38]$ Therefore, additional toxicity studies of $\mathrm{CeO}_{2} \mathrm{NPs}$ would be necessary considering their various physicochemical properties and exposure scenarios.

In conclusion, under the experimental conditions of this study design, there were no $\mathrm{CeO}_{2} \mathrm{NPs}$-related adverse effects in terms of general systemic signs as well as development and reproduction, at doses up to $1000 \mathrm{mg} / \mathrm{kg}$. In addition, $\mathrm{CeO}_{2}$ NPs were not deposited in the parental or pup internal organs after repeated oral exposure. These results in this study could be used for the risk assessment of repeated $\mathrm{CeO}_{2} \mathrm{NPs}$ exposure in humans, and further toxicity studies will be necessary to understand the potential risk to humans considering the various physicochemical properties and exposure scenarios of $\mathrm{CeO}_{2} \mathrm{NPs}$.

\section{Abbreviations}

AAALAC:Association for Assessment and Accreditation of Laboratory Animal Care International, ANCOVA:Analysis of covariance, ANOVA:Analysis of variance, A/G:Albumin/globulin ratio, ALB:Albumin, APTT:Activated partial thromboplastin time, AST:Aspartate aminotransferase, BAS:Basophils, BUN:Blood urea nitrogen, $\mathrm{Ca}$ :Calcium, $\mathrm{CeO}_{2} \mathrm{NPs}$ :Cerium oxide nanoparticles, $\mathrm{Cl}$ :Chloride, $\mathrm{CREA}$ :Creatinine, CK:Creatine phosphokinase, DLS:Dynamic light scattering, EDTA:Ethylenediaminetetraacetic acid, EDX:Energy-dispersive X-ray, EOS:Eosinophils, EU REACH:European Registration, Evaluation, Authorisation and Restriction of Chemicals, GD:Gestation day, GGT:Gamma glutamyl transpeptidase, GLP:Good laboratory practice, GLU:Glucose, HCT:Hematocrit, HGB:Hemoglobin, IACUC:Institutional Animal Care and Use Committee, ICP-AES:Inductively coupled plasma atomic emission spectroscopy, IP:Inorganic phosphorus, K:Potassium, KIT:Korea Institute of Toxicology, LD:Lactation day, LYM:Lymphocytes, MCH:Mean corpuscular hemoglobin, MCHC:Mean corpuscular hemoglobin concentration, MCV:Mean corpuscular volume, MON:Monocytes, Na:Sodium, NEU:Neutrophils, OECD:Organization for Economic Co-operation and Development, PL:Phospholipid, PLT:Platelet count, PND:Post-natal day, PT:Prothrombin time, RBC:Red blood cell count, SD:Sprague-Dawley, TCHO:Total cholesterol, TEM:Transmission electron microscopy, TG:Triglyceride, TP:Total protein, WBC:White blood cell count

\section{Declarations}




\section{ACKNOWLEDGMENTS}

The authors would like to especially thank the technical staff of the developmental and reproductive toxicology research group at KIT for their technical support.

\section{FUNDING}

This work was supported by the National Institute of Environmental Research (Grant No. NIER-SP2013141).

\section{Availability of data and materials}

The relevant datasets supporting the conclusions of this article are included within the article, and all datasets used and analyzed during the current study are available from the corresponding author on reasonable request.

\section{Authors' contributions}

JL, EJJ, SYN and WJY conceived and designed the present study. JL, JSJ, SJL and SYK managed the inlife observation experiments, and WJI managed the terminal observation experiments. KP conducted the cerium distribution analysis. JL, JSJ and SHK analyzed the physicochemical properties of particles. JL, YJS and WJY interpreted the data and wrote the manuscript. All authors reviewed and approved the final manuscript.

\section{Ethics approval}

All animal protocols were prepared in accordance with the Animal Protection Act of Korea and Guide for the Care and Use of Laboratory Animals published by the Institute for Laboratory Animal Research (ILAR). This animal study was approved by the Institutional Animal Care and Use Committee (IACUC) of KIT.

\section{Competing interests}

The authors declare that they have no competing interests.

\section{CONSENT FOR PUBLICATION}

Not applicable

\section{CONSENT TO PARTICIPATE}

Not applicable

\section{References}


1. Berube DM, Searson EM, Morton TS, Cummings CL. Project on emerging nanotechnologiesconsumer product inventory evaluated. Nanotech L \& Bus. 2010;7:152.

2. OECD. Series on the Safety of Manufactured Nanomaterials, Document No. 6, List of Manufactured Nanomaterials and List of Endpoints for Phase One of the OECD Testing Programme. . 2008.

3. Korsvik C, Patil S, Seal S, Self WT. Superoxide dismutase mimetic properties exhibited by vacancy engineered ceria nanoparticles. Chemical communications. 2007; 10:1056-8.

4. Cassee FR, van Balen EC, Singh C, Green D, Muijser H, Weinstein J, et al. Exposure, health and ecological effects review of engineered nanoscale cerium and cerium oxide associated with its use as a fuel additive. Critical reviews in toxicology. 2011;41 3:213-29.

5. Murray EP, Tsai T, Barnett SA. A direct-methane fuel cell with a ceria-based anode. Nature. 1999;400 6745:649.

6. Sun C, Li H, Chen L. Nanostructured ceria-based materials: synthesis, properties, and applications. Energy \& Environmental Science. 2012;5 9:8475-505.

7. Wu W, Li S, Liao S, Xiang F, Wu X. Preparation of new sunscreen materials Ce 1- x Zn x O 2- x via solid-state reaction at room temperature and study on their properties. Rare Metals. 2010;29 2:14953.

8. Rodea-Palomares I, Boltes K, Fernández-Pinas F, Leganés F, García-Calvo E, Santiago J, et al. Physicochemical characterization and ecotoxicological assessment of $\mathrm{CeO} 2$ nanoparticles using two aquatic microorganisms. Toxicological Sciences. 2010;119 1:135-45.

9. Park E-J, Choi J, Park Y-K, Park K. Oxidative stress induced by cerium oxide nanoparticles in cultured BEAS-2B cells. Toxicology. 2008;245 1-2:90-100.

10. Srinivas A, Rao PJ, Selvam G, Murthy PB, Reddy PN. Acute inhalation toxicity of cerium oxide nanoparticles in rats. Toxicology Letters. 2011;205 2:105-15.

11. Yokel RA, Au TC, MacPhail R, Hardas SS, Butterfield DA, Sultana R, et al. Distribution, elimination, and biopersistence to 90 days of a systemically introduced $30 \mathrm{~nm}$ ceria-engineered nanomaterial in rats. Toxicological Sciences. 2012;127 1:256-68.

12. OECD. Test No. 422: Combined Repeated Dose Toxicity Study with the Reproduction/Developmental Toxicity Screening Test. 1996.

13. OECD. OECD Principles on Good Laboratory Practice. 1997.

14. Council NR. Guide for the care and use of laboratory animals. National Academies Press; 2010.

15. Lee J, Jeong J-S, Kim SY, Park M-K, Choi S-D, Kim U-J, et al. Titanium dioxide nanoparticles oral exposure to pregnant rats and its distribution. Particle and Fibre Toxicology. 2019;16 1:31.

16. Park K, Park J, Lee H, Choi J, Yu W-J, Lee J. Toxicity and tissue distribution of cerium oxide nanoparticles in rats by two different routes: single intravenous injection and single oral administration. Archives of pharmacal research. 2018;41 11:1108-16.

17. Lee J, Jeong J-S, Cho K-J, Moon K-N, Kim SY, Han B, et al. Developmental and reproductive toxicity assessment in rats with KGC-HJ3, Korean Red Ginseng with Angelica gigas and Deer antlers. Journal 
of ginseng research. 2019;43 2:242-51.

18. Hendren CO, Mesnard X, Dröge J, Wiesner MR: Estimating production data for five engineered nanomaterials as a basis for exposure assessment. ACS Publications; 2011.

19. Hoecke KV, Quik JT, Mankiewicz-Boczek J, Schamphelaere KAD, Elsaesser A, Meeren PVd, et al. Fate and effects of $\mathrm{CeO} 2$ nanoparticles in aquatic ecotoxicity tests. Environmental science \& technology. 2009;43 12:4537-46.

20. Pierscionek BK, Li Y, Yasseen AA, Colhoun LM, Schachar RA, Chen W. Nanoceria have no genotoxic effect on human lens epithelial cells. Nanotechnology. 2009;21 3:035102.

21. Lin W, Huang Y-w, Zhou X-D, Ma Y. Toxicity of cerium oxide nanoparticles in human lung cancer cells. International journal of toxicology. 2006;25 6:451-7.

22. Cheng G, Guo W, Han L, Chen E, Kong L, Wang L, et al. Cerium oxide nanoparticles induce cytotoxicity in human hepatoma SMMC-7721 cells via oxidative stress and the activation of MAPK signaling pathways. Toxicology in Vitro. 2013;27 3:1082-8.

23. Park E-J, Park Y-K, Park K-S. Acute toxicity and tissue distribution of cerium oxide nanoparticles by a single oral administration in rats. Toxicological Research. 2009;25 2:79-84.

24. Hirst SM, Karakoti A, Singh S, Self W, Tyler R, Seal S, et al. Bio-distribution and in vivo antioxidant effects of cerium oxide nanoparticles in mice. Environmental toxicology. 2013;28 2:107-18.

25. Kumari M, Kumari SI, Grover P. Genotoxicity analysis of cerium oxide micro and nanoparticles in Wistar rats after 28 days of repeated oral administration. Mutagenesis. 2014;29 6:467-79.

26. Minarchick VC, Stapleton PA, Fix NR, Leonard SS, Sabolsky EM, Nurkiewicz TR. Intravenous and gastric cerium dioxide nanoparticle exposure disrupts microvascular smooth muscle signaling. Toxicological Sciences. 2015;144 1:77-89.

27. Beekhuijzen M, de Raaf MA, Zmarowski A, van Otterdijk F, Peter B, Emmen H. The underestimated value of OECD 421 and 422 repro screening studies: Putting it in the right perspective. Reproductive Toxicology. 2014;48:81-7.

28. Hood RD, Hood RD. Developmental and reproductive toxicology: a practical approach. CRC press; 2016.

29. Carney E, Zablotny C, Marty M, Crissman J, Anderson P, Woolhiser M, et al. The effects of feed restriction during in utero and postnatal development in rats. Toxicological Sciences. 2004;82 1:23749.

30. Romero A, Villamayor F, Grau M, Sacristan A, Ortiz J. Relationship between fetal weight and litter size in rats: application to reproductive toxicology studies. Reproductive Toxicology. 1992;6 5:453-6.

31. ECHA. Guidance on information requirements and chemical safety assessment. Chapter R.7a: Endpoint specific guidance. 2017.

32. Geraets L, Oomen AG, Schroeter JD, Coleman VA, Cassee FR. Tissue Distribution of Inhaled Microand Nano-sized Cerium Oxide Particles in Rats: Results From a 28-Day Exposure Study. Toxicological Sciences. 2012;127 2:463-73; doi: 10.1093/toxsci/kfs113. https://doi.org/10.1093/toxsci/kfs113. 
33. He X, Zhang H, Ma Y, Bai W, Zhang Z, Lu K, et al. Lung deposition and extrapulmonary translocation of nano-ceria after intratracheal instillation. Nanotechnology. 2010;21 28:285103.

34. Nel A, Xia T, Mädler L, Li N. Toxic potential of materials at the nanolevel. science. 2006;311 5761:6227.

35. Wang J, Zhou G, Chen C, Yu H, Wang T, Ma Y, et al. Acute toxicity and biodistribution of different sized titanium dioxide particles in mice after oral administration. Toxicology letters. 2007;168 2:17685.

36. Song M, Yuan S, Yin J, Wang X, Meng Z, Wang H, et al. Size-dependent toxicity of nano-C60 aggregates: more sensitive indication by apoptosis-related Bax translocation in cultured human cells. Environmental science \& technology. 2012;46 6:3457-64.

37. Máté Z, Horváth E, Kozma G, Simon T, Kónya Z, Paulik E, et al. Size-Dependent Toxicity Differences of Intratracheally Instilled Manganese Oxide Nanoparticles: Conclusions of a Subacute Animal Experiment. Biological Trace Element Research. 2016;171 1:156-66; doi: 10.1007/s12011-015-0508z. https://doi.org/10.1007/s12011-015-0508-z.

38. Hansen SF, Michelson ES, Kamper A, Borling P, Stuer-Lauridsen F, Baun A. Categorization framework to aid exposure assessment of nanomaterials in consumer products. Ecotoxicology. 2008;17 5:43847.

\section{Tables}

[Due to technical limitations, table 1 could not be displayed here. Please see the supplementary files to access table 1.]

\section{Table 2}

Food consumption of $\mathrm{CeO}_{2}$ NPs-treated males and females during the study period 


\begin{tabular}{llll}
\hline 0 & 100 & 300 & 1000 \\
\hline
\end{tabular}

\section{Males}

Pre-mating day 1-4 (g)

Pre-mating day 4-8 (g)

Pre-mating day 8-11 (g)

Pre-mating day 11-14 (g)

Total period (g, pre-mating day 1 to 14 )

\section{Females}

Pre-mating day 1-4 (g)

Pre-mating day 4-8 (g)

Pre-mating day 8-11 (g)

Pre-mating day 11-14 (g)

Gestation day 0-7 (g)

Gestation day 7-14 (g)

Gestation day 14-20 (g)

Post-natal day 0-4 (g)

Total period ( $\mathrm{g}$, pre-mating day 1 to lactation day 4 )

$\begin{array}{rrrr}30.6 \pm & 29.3 \pm & 28.6 \pm & 30.5 \pm \\ 1.94 & 0.76 & 1.53^{*} & 1.55 \\ 31.3 \pm & 30.4 \pm & 30.2 \pm & 31.2 \pm \\ 2.17 & 1.17 & 1.61 & 1.36 \\ 31.4 \pm & 31.5 \pm & 30.5 \pm & 32.2 \pm \\ 2.27 & 1.48 & 2.34 & 1.16 \\ 32.3 \pm & 32.6 \pm & 31.4 \pm & 32.7 \pm \\ 2.04 & 1.81 & 2.38 & 1.13 \\ 31.4 \pm & 30.9 \pm & 30.2 \pm & 31.7 \pm \\ 2.01 & 1.13 & 1.85 & 1.04\end{array}$

$\begin{array}{rrrr}21.1 \pm & 20.2 \pm & 21.3 \pm & 21.2 \pm \\ 1.62 & 1.09 & 1.07 & 1.62 \\ 21.8 \pm & 21.4 \pm & 22.7 \pm & 22.2 \pm \\ 1.19 & 0.77 & 1.22 & 1.63 \\ 21.9 \pm & 22.3 \pm & 23.0 \pm & 22.1 \pm \\ 1.65 & 1.35 & 2.22 & 1.85 \\ 23.0 \pm & 23.0 \pm & 23.7 \pm & 23.3 \pm \\ 1.50 & 1.47 & 0.76 & 1.93 \\ 25.6 \pm & 26.0 \pm & 25.7 \pm & 26.8 \pm \\ 1.70 & 2.56 & 2.15 & 1.40 \\ 25.5 \pm & 25.9 \pm & 25.9 \pm & 25.8 \pm \\ 1.52 & 2.31 & 2.26 & 1.97 \\ 29.8 \pm & 29.2 \pm & 29.3 \pm & 31.5 \pm \\ 2.13 & 1.89 & 1.87 & 2.02 \\ 35.8 \pm & 36.8 \pm & 35.9 \pm & 40.1 \pm \\ 5.01 & 3.19 & 6.13 & 4.06 \\ 25.0 \pm & 25.0 \pm & 25.4 \pm & 25.9 \pm \\ 1.13 & 1.36 & 1.23 & 1.28\end{array}$

* Represent a significant difference at the $\mathbf{p}<0.05$ level compared to the vehicle control $(n=12$, mean \pm SD)

\section{Table 3}

Hematology results of $\mathrm{CeO}_{2}$ NPs-treated males and females during the study period 


\section{Males}

$\operatorname{RBC}\left(10^{6} / \mathrm{mL}\right)$

HGB (g/dL)

HCT (\%)

MCV (fL)

$\mathrm{MCH}$ (pg)

$\mathrm{MCHC}(\mathrm{g} / \mathrm{dL})$

PLT $\left(10^{3} / \mathrm{mL}\right)$

RET (\%)

RETA $\left(10^{9} / \mathrm{mL}\right)$

WBC $\left(10^{3} / \mathrm{mL}\right)$

NEU (\%)

NEUA $\left(10^{3} / \mathrm{mL}\right)$

LYM (\%)

LYMA $\left(10^{3} / \mathrm{mL}\right)$

EOS (\%)

EOSA $\left(10^{3} / \mathrm{mL}\right)$

MON (\%)

MONA $\left(10^{3} / \mathrm{mL}\right)$

BAS (\%)

BASA $\left(10^{3} / \mathrm{mL}\right)$

LUC (\%)

LUCA $\left(10^{3} / \mathrm{mL}\right)$

PT (sec)

APTT (sec)
$9.1 \pm 0.38$

$16.6 \pm 0.61$

$51.0 \pm 2.50$

$56.1 \pm 1.69$

$18.3 \pm 0.43$

$32.5 \pm 0.42$

$1130.8 \pm$ 149.70

$2.5 \pm 0.46$ $223.8 \pm 41.42$

$10.6 \pm 3.32$

$14.8 \pm 6.90$

$1.5 \pm 0.74$

$81.3 \pm 6.68$

$8.7 \pm 2.82$

$0.8 \pm 0.24$

$0.09 \pm 0.052$

$1.9 \pm 0.55$

$0.2 \pm 0.13$

$0.6 \pm 0.11$

$0.06 \pm 0.021$

$0.7 \pm 0.27$

$0.07 \pm 0.050$

$14.0 \pm 1.68$

$17.5 \pm 0.72$
$9.1 \pm 0.28$

$16.9 \pm 0.43$

$51.4 \pm 2.04$

$56.2 \pm 0.93$

$18.5 \pm 0.30$

$33.0 \pm 0.73$

$1024.2 \pm$ 133.65

$2.5 \pm 0.31$

$226.0 \pm 22.21$

$11.6 \pm 4.11$

$11.4 \pm 1.72$

$1.4 \pm 0.68$

$84.7 \pm 2.09$

$9.8 \pm 3.26$

$0.9 \pm 0.18$

$0.10 \pm 0.030$

$1.9 \pm 0.62$

$0.3 \pm 0.15$

$0.5 \pm 0.09$

$0.06 \pm 0.028$

$0.6 \pm 0.12$

$0.07 \pm 0.035$

$13.7 \pm 0.84$

$18.0 \pm 0.78$
$8.9 \pm 0.53$

$16.8 \pm 0.55$

$50.7 \pm 2.10$

$57.2 \pm 1.77$

$18.9 \pm 0.68$

$33.1 \pm 0.59$

$940.4 \pm 41.25$

$2.5 \pm 0.28$

$223.8 \pm 31.62$

$12.4 \pm 1.03$

$12.1 \pm 2.95$

$1.5 \pm 0.47$

$83.2 \pm 3.63$

$10.3 \pm 0.72$

$0.9 \pm 0.33$

$0.12 \pm 0.052$

$2.3 \pm 0.73$

$0.3 \pm 0.09$

$0.7 \pm 0.10$

$0.09 \pm 0.005$

$0.7 \pm 0.10$

$0.09 \pm 0.023$

$16.0 \pm 2.74$

$18.3 \pm 0.87$
$8.9 \pm 0.10$

$16.8 \pm 0.63$

$50.4 \pm 2.13$

$56.9 \pm 1.86$

$18.9 \pm 0.52$

$33.3 \pm 0.35$

$1101.6 \pm 84.75$

$2.5 \pm 0.55$

$218.4 \pm 48.74$

$11.0 \pm 2.17$

$13.4 \pm 2.47$

$1.5 \pm 0.48$

$81.7 \pm 2.02$

$9.0 \pm 1.74$

$1.0 \pm 0.36$

$0.11 \pm 0.038$

$2.5 \pm 0.56$

$0.3 \pm 0.03$

$0.6 \pm 0.20$

$0.06 \pm 0.009$

$0.8 \pm 0.13$ $0.09 \pm 0.012$

$13.6 \pm 0.73$

$17.8 \pm 0.99$

\section{Females}

$\operatorname{RBC}\left(10^{6} / \mathrm{mL}\right)$

HGB $(\mathrm{g} / \mathrm{dL})$

HCT (\%)

MCV (fL)

$\mathrm{MCH}$ (pg)

$\mathrm{MCHC}(\mathrm{g} / \mathrm{dL})$

PLT $\left(10^{3} / \mathrm{mL}\right)$

RET (\%)

RETA $\left(10^{9} / \mathrm{mL}\right)$

WBC $\left(10^{3} / \mathrm{mL}\right)$

NEU (\%)

NEUA $\left(10^{3} / \mathrm{mL}\right)$

LYM (\%)

$7.8 \pm 0.50$

$14.9 \pm 0.89$

$46.0 \pm 2.56$

$59.4 \pm 0.91$

$19.3 \pm 0.23$

$32.5 \pm 0.51$

$1351.0 \pm$ 167.25

$5.8 \pm 1.26$ $448.3 \pm 78.31$

$9.5 \pm 2.47$

$12.2 \pm 4.95$

$1.2 \pm 0.68$

$81.5 \pm 5.15$
$7.7 \pm 0.33$

$14.8 \pm 0.25$

$45.6 \pm 1.35$

$59.4 \pm 1.22$

$19.3 \pm 0.51$

$32.5 \pm 0.45$

$1213.2 \pm$

174.16

$6.4 \pm 1.72$ $492.2 \pm 142.86$

$9.8 \pm 2.40$

$13.3 \pm 2.15$

$1.3 \pm 0.30$

$80.5 \pm 1.99$
$7.9 \pm 0.51$

$14.8 \pm 0.86$

$45.5 \pm 2.72$

$57.9 \pm 1.96$

$18.8 \pm 0.67$

$32.5 \pm 0.42$

$1258.4 \pm$ 222.70

$6.3 \pm 1.44$ $489.7 \pm 77.76$

$11.2 \pm 1.14$

$12.8 \pm 3.21$

$1.4 \pm 0.21$

$80.7 \pm 4.04$
$8.1 \pm 0.17$

$15.3 \pm 0.52$ $47.0 \pm 1.48$ $58.2 \pm 1.17$ $18.9 \pm 0.29$ $32.4 \pm 0.39$ $1305.0 \pm$ 253.02

$6.2 \pm 1.65$ $502.9 \pm 136.39$

$12.8 \pm 3.22$

$13.2 \pm 2.78$

$1.7 \pm 0.75$

$80.3 \pm 3.15$ 


\begin{tabular}{lrrrr}
\cline { 2 - 5 } & $\mathbf{0}$ & $\mathbf{1 0 0}$ & $\mathbf{3 0 0}$ & $\mathbf{1 0 0 0}$ \\
\hline LYMA $\left(10^{3} / \mathrm{mL}\right)$ & $7.7 \pm 2.04$ & $7.9 \pm 2.06$ & $9.1 \pm 1.36$ & $10.2 \pm 2.30$ \\
EOS $(\%)$ & $0.8 \pm 0.35$ & $0.6 \pm 0.24$ & $0.7 \pm 0.26$ & $0.7 \pm 0.32$ \\
EOSA $\left(10^{3} / \mathrm{mL}\right)$ & $0.07 \pm 0.021$ & $0.06 \pm 0.038$ & $0.07 \pm 0.023$ & $0.09 \pm 0.038$ \\
MON $(\%)$ & $4.3 \pm 0.68$ & $4.0 \pm 1.17$ & $4.6 \pm 0.94$ & $4.6 \pm 0.77$ \\
MONA $\left(10^{3} / \mathrm{mL}\right)$ & $0.4 \pm 0.09$ & $0.4 \pm 0.11$ & $0.5 \pm 0.08$ & $0.6 \pm 0.21$ \\
BAS $(\%)$ & $0.5 \pm 0.11$ & $0.5 \pm 0.21$ & $0.4 \pm 0.08$ & $0.4 \pm 0.08$ \\
BASA $\left(10^{3} / \mathrm{mL}\right)$ & $0.04 \pm 0.013$ & $0.05 \pm 0.031$ & $0.05 \pm 0.008$ & $0.05 \pm 0.020$ \\
LUC $(\%)$ & $0.8 \pm 0.26$ & $1.1 \pm 0.13$ & $0.8 \pm 0.29$ & $0.8 \pm 0.23$ \\
LUCA $\left(10^{3} / \mathrm{mL}\right)$ & $0.07 \pm 0.013$ & $0.10 \pm 0.025$ & $0.09 \pm 0.030$ & $0.10 \pm 0.026$ \\
PT $(\mathrm{sec})$ & $13.6 \pm 1.17$ & $15.5 \pm 0.29 *$ & $15.3 \pm 0.94$ & $14.4 \pm 1.54$ \\
APTT $(\mathrm{sec})$ & $16.1 \pm 0.72$ & $15.6 \pm 1.15$ & $14.8 \pm 1.01$ & $15.0 \pm 0.93$ \\
& & & & \\
\hline
\end{tabular}

* Represent a significant difference at the $\mathbf{p}<0.05$ level compared to the vehicle control $(n=5$, mean $\pm S D)$.

\section{Table 4}

Clinical chemistry results of $\mathrm{CeO}_{2}$ NPs-treated males and females during the study period 


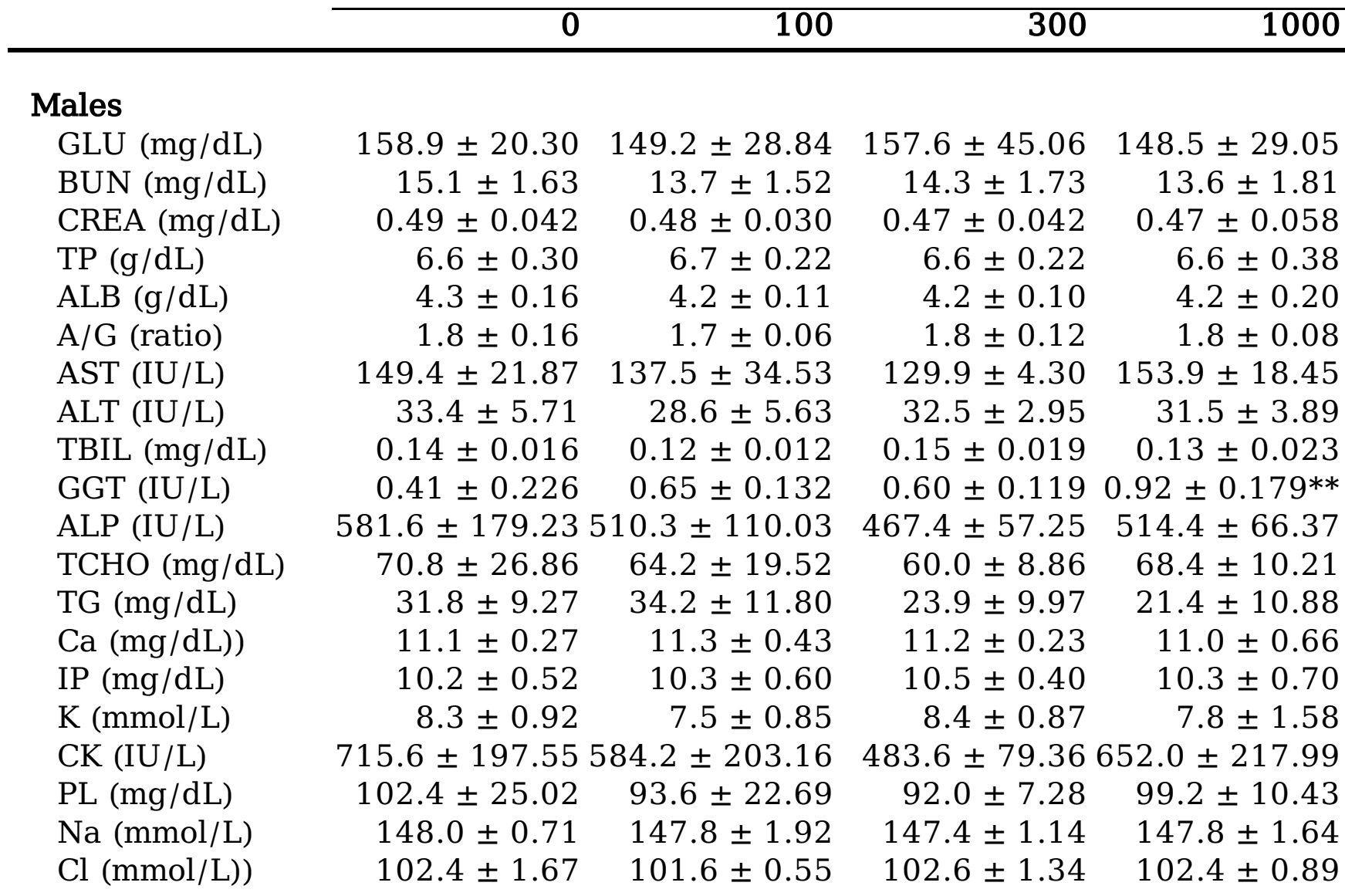

\section{Females}

GLU (mg/dL)

BUN (mg/dL)

CREA (mg/dL)

TP (g/dL)

ALB (g/dL)

A/G (ratio)

AST (IU/L)

ALT (IU/L)

TBIL (mg/dL)

GGT (IU/L)

ALP (IU/L)

TCHO (mg/dL)

TG (mg/dL)

$\mathrm{Ca}(\mathrm{mg} / \mathrm{dL}))$

IP $(\mathrm{mg} / \mathrm{dL})$

$\mathrm{K}(\mathrm{mmol} / \mathrm{L})$

CK (IU/L)

$\mathrm{PL}(\mathrm{mg} / \mathrm{dL})$

$\mathrm{Na}(\mathrm{mmol} / \mathrm{L})$

$\mathrm{Cl}(\mathrm{mmol} / \mathrm{L}))$
$131.2 \pm 22.43 \quad 116.0 \pm 15.10$ $24.1 \pm 4.71$ $0.57 \pm 0.077$

$7.0 \pm 0.42$

$4.5 \pm 0.22$

$1.8 \pm 0.10$

$142.7 \pm 44.27$

$40.2 \pm 8.01$

$0.13 \pm 0.018$

$0.59 \pm 0.224$

$332.3 \pm 111.04$

$49.8 \pm 16.04$

$38.9 \pm 22.46$

$11.7 \pm 0.38$

$9.9 \pm 0.81$

$8.6 \pm 0.52$
$19.4 \pm 3.38$

$0.51 \pm 0.032$

$7.0 \pm 0.41$

$4.6 \pm 0.27$

$2.0 \pm 0.16$

$129.1 \pm 23.12$

$41.5 \pm 8.14$

$0.12 \pm 0.015$

$0.78 \pm 0.104$

$293.1 \pm 58.04$

$58.0 \pm 16.46$

$36.9 \pm 13.14$

$11.8 \pm 0.46$

$10.2 \pm 0.05$

$8.3 \pm 0.45$
$108.8 \pm 10.68$

$21.2 \pm 4.13$

$0.54 \pm 0.041$

$7.00 \pm 0.21$

$4.5 \pm 0.13$

$1.9 \pm 0.06$

$135.6 \pm 17.69$

$45.1 \pm 5.18$

$0.13 \pm 0.016$

$0.67 \pm 0.268$

$232.7 \pm 31.73$

$53.8 \pm 10.78$

$41.7 \pm 14.91$

$11.7 \pm 0.26$

$10.3 \pm 1.19$

$8.2 \pm 1.12$
$139.1 \pm 17.09$

$20.3 \pm 3.60$

$0.56 \pm 0.034$

$7.1 \pm 0.25$

$4.6 \pm 0.12$

$1.9 \pm 0.08$

$121.3 \pm 8.02$

$39.8 \pm 2.57$

$0.12 \pm 0.018$

$0.71 \pm 0.384$

$267.1 \pm 83.92$

$55.2 \pm 12.79$

$54.7 \pm 25.54$

$11.9 \pm 0.20$

$9.8 \pm 0.71$

$8.2 \pm 1.67$

$611.8 \pm 331.76518 .0 \pm 112.86570 .6 \pm 129.05448 .8 \pm 130.31$ $106.8 \pm 26.92 \quad 116.8 \pm 24.76$ $144.8 \pm 1.30 \quad 145.0 \pm 1.87$ $108.6 \pm 14.77$

$115.8 \pm 19.10$ $101.4 \pm 0.55 \quad 101.2 \pm 1.48$

$145.0 \pm 1.41$

$101.6 \pm 1.14$
$146.0 \pm 1.58$

$102.2 \pm 2.39$ 
** Represent a significant difference at the $\mathbf{p}<0.01$ level compared to the vehicle control $(n=5$, mean \pm SD).

\section{Table 5}

Absolute and relative organ weights of $\mathrm{CeO}_{2}$ NPs-treated males during the study period 


\begin{tabular}{|c|c|c|c|c|c|}
\hline & & 0 & 100 & 300 & 1000 \\
\hline \multirow[t]{2}{*}{$\begin{array}{l}\text { Terminal } \\
\text { weight (g) }\end{array}$} & body (g) & $\begin{array}{r}427.0 \pm \\
38.68\end{array}$ & $\begin{array}{r}439.2 \pm \\
23.73\end{array}$ & $\begin{array}{r}436.4 \pm \\
36.00\end{array}$ & $\begin{array}{r}448.9 \pm \\
28.64\end{array}$ \\
\hline & $\mathrm{N}$ & 12 & 12 & 12 & 12 \\
\hline \multirow[t]{3}{*}{ Adrenal glands } & $\begin{array}{l}\text { Absolute } \\
\text { (g) }\end{array}$ & $0.06 \pm 0.010$ & $0.07 \pm 0.005$ & $0.06 \pm 0.013$ & $0.07 \pm 0.004$ \\
\hline & $\begin{array}{l}\text { Relative } \\
(\%)\end{array}$ & $\begin{array}{r}0.016 \pm \\
0.0027\end{array}$ & $\begin{array}{r}0.016 \pm \\
0.0016\end{array}$ & $\begin{array}{r}0.016 \pm \\
0.0021\end{array}$ & $\begin{array}{r}0.015 \pm \\
0.0009\end{array}$ \\
\hline & $\mathrm{N}$ & 5 & 5 & 5 & 5 \\
\hline \multirow[t]{3}{*}{ Brain } & $\begin{array}{l}\text { Absolute } \\
\text { (g) }\end{array}$ & $1.97 \pm 0.119$ & $1.99 \pm 0.065$ & $2.03 \pm 0.092$ & $2.00 \pm 0.116$ \\
\hline & $\begin{array}{l}\text { Relative } \\
(\%)\end{array}$ & $\begin{array}{r}0.484 \pm \\
0.0680\end{array}$ & $\begin{array}{r}0.460 \pm \\
0.0233\end{array}$ & $\begin{array}{r}0.497 \pm \\
0.0302\end{array}$ & $\begin{array}{c}0.461 \pm \\
0.0126\end{array}$ \\
\hline & $\mathrm{N}$ & 5 & 5 & 5 & 5 \\
\hline \multirow[t]{3}{*}{ Heart } & $\begin{array}{l}\text { Absolute } \\
\text { (g) }\end{array}$ & $1.25 \pm 0.124$ & $1.29 \pm 0.144$ & $1.33 \pm 0.130$ & $1.32 \pm 0.106$ \\
\hline & $\begin{array}{l}\text { Relative } \\
(\%)\end{array}$ & $\begin{array}{r}0.304 \pm \\
0.0233\end{array}$ & $\begin{array}{r}0.300 \pm \\
0.0302\end{array}$ & $\begin{array}{r}0.325 \pm \\
0.0244\end{array}$ & $\begin{array}{r}0.303 \pm \\
0.0278\end{array}$ \\
\hline & $\mathrm{N}$ & 5 & 5 & 5 & 5 \\
\hline \multirow[t]{3}{*}{ Kidneys } & $\begin{array}{l}\text { Absolute } \\
\text { (g) }\end{array}$ & $3.25 \pm 0.192$ & $3.40 \pm 0.150$ & $3.50 \pm 0.334$ & $3.47 \pm 0.415$ \\
\hline & $\begin{array}{l}\text { Relative } \\
(\%)\end{array}$ & $\begin{array}{r}0.794 \pm \\
0.0711\end{array}$ & $\begin{array}{c}0.788 \pm \\
0.0501\end{array}$ & $\begin{array}{r}0.854 \pm \\
0.0468\end{array}$ & $\begin{array}{r}0.797 \pm \\
0.0703\end{array}$ \\
\hline & $\mathrm{N}$ & 5 & 5 & 5 & 5 \\
\hline \multirow[t]{3}{*}{ Liver } & $\begin{array}{l}\text { Absolute } \\
\text { (g) }\end{array}$ & $\begin{array}{r}11.71 \pm \\
2.072\end{array}$ & $\begin{array}{r}12.74 \pm \\
0.706\end{array}$ & $\begin{array}{r}12.12 \pm \\
2.086\end{array}$ & $\begin{array}{r}12.51 \pm \\
1.408\end{array}$ \\
\hline & $\begin{array}{l}\text { Relative } \\
(\%)\end{array}$ & $\begin{array}{r}2.825 \pm \\
0.2167\end{array}$ & $\begin{array}{r}2.950 \pm \\
0.1063\end{array}$ & $\begin{array}{r}2.940 \pm \\
0.2455\end{array}$ & $\begin{array}{r}2.870 \pm \\
0.1972\end{array}$ \\
\hline & $\mathrm{N}$ & 5 & 5 & 5 & 5 \\
\hline \multirow[t]{3}{*}{ Pituitary gland } & $\begin{array}{l}\text { Absolute } \\
\text { (g) }\end{array}$ & $0.01 \pm 0.002$ & $0.01 \pm 0.001$ & $0.01 \pm 0.002$ & $0.01 \pm 0.001$ \\
\hline & $\begin{array}{l}\text { Relative } \\
(\%)\end{array}$ & $\begin{array}{r}0.003 \pm \\
0.0001\end{array}$ & $\begin{array}{r}0.003 \pm \\
0.0002\end{array}$ & $\begin{array}{r}0.003 \pm \\
0.0002\end{array}$ & $\begin{array}{r}0.003 \pm \\
0.0003\end{array}$ \\
\hline & $\mathrm{N}$ & 5 & 5 & 5 & 5 \\
\hline \multirow[t]{3}{*}{ Prostate } & $\begin{array}{l}\text { Absolute } \\
\text { (g) }\end{array}$ & $0.62 \pm 0.122$ & $0.59 \pm 0.170$ & $0.66 \pm 0.128$ & $0.65 \pm 0.093$ \\
\hline & $\begin{array}{l}\text { Relative } \\
(\%)\end{array}$ & $\begin{array}{r}0.144 \pm \\
0.0258\end{array}$ & $\begin{array}{r}0.135 \pm \\
0.0407\end{array}$ & $\begin{array}{r}0.151 \pm \\
0.0314\end{array}$ & $\begin{array}{r}0.146 \pm \\
0.0177\end{array}$ \\
\hline & $\mathrm{N}$ & 12 & $\begin{array}{ll}2 & 12\end{array}$ & 12 & 12 \\
\hline \multirow[t]{3}{*}{ Spleen } & $\begin{array}{l}\text { Absolute } \\
\text { (g) }\end{array}$ & $0.66 \pm 0.131$ & $0.67 \pm 0.152$ & $0.65 \pm 0.133$ & $0.69 \pm 0.082$ \\
\hline & $\begin{array}{l}\text { Relative } \\
(\%)\end{array}$ & $\begin{array}{r}0.158 \pm \\
0.0134\end{array}$ & $\begin{array}{r}0.155 \pm \\
0.0331\end{array}$ & $\begin{array}{r}0.158 \pm \\
0.0199\end{array}$ & $\begin{array}{r}0.158 \pm \\
0.0127\end{array}$ \\
\hline & $\mathrm{N}$ & 5 & $5 \quad 5$ & 5 & 5 \\
\hline \multirow[t]{2}{*}{ Thymus } & $\begin{array}{l}\text { Absolute } \\
\text { (g) }\end{array}$ & $0.34 \pm 0.024$ & $0.39 \pm 0.076$ & $0.35 \pm 0.106$ & $0.32 \pm 0.057$ \\
\hline & $\begin{array}{l}\text { Relative } \\
(\%)\end{array}$ & $\begin{array}{r}0.083 \pm \\
0.0099\end{array}$ & $\begin{array}{r}0.090 \pm \\
0.0179\end{array}$ & $\begin{array}{r}0.084 \pm \\
0.0193\end{array}$ & $\begin{array}{r}0.072 \pm \\
0.0112\end{array}$ \\
\hline
\end{tabular}




\begin{tabular}{|c|c|c|c|c|c|}
\hline & & 0 & 100 & 300 & 1000 \\
\hline \multirow{4}{*}{ Lungs } & $\overline{\mathrm{N}}$ & 5 & 5 & 5 & 5 \\
\hline & $\begin{array}{l}\text { Absolute } \\
\text { (g) }\end{array}$ & $1.50 \pm 0.126$ & $1.58 \pm 0.120$ & $1.57 \pm 0.173$ & $1.62 \pm 0.067$ \\
\hline & $\begin{array}{l}\text { Relative } \\
\text { (\%) }\end{array}$ & $\begin{array}{r}0.367 \pm \\
0.0411\end{array}$ & $\begin{array}{r}0.367 \pm \\
0.0314\end{array}$ & $\begin{array}{r}0.383 \pm \\
0.0205\end{array}$ & $\begin{array}{r}0.374 \pm \\
0.0205\end{array}$ \\
\hline & $\mathrm{N}$ & 5 & 5 & 5 & 5 \\
\hline \multirow[t]{3}{*}{ Right testis } & $\begin{array}{l}\text { Absolute } \\
\text { (g) }\end{array}$ & $1.70 \pm 0.169$ & $1.74 \pm 0.134$ & $=1.69 \pm 0.109$ & $1.65 \pm 0.120$ \\
\hline & $\begin{array}{l}\text { Relative } \\
\text { (\%) }\end{array}$ & $\begin{array}{r}0.400 \pm \\
0.0492\end{array}$ & $\begin{array}{r}0.396 \pm \\
0.0313\end{array}$ & $\begin{array}{c}0.391 \pm \\
0.0514\end{array}$ & $\begin{array}{r}0.369 \pm \\
0.0280\end{array}$ \\
\hline & $\mathrm{N}$ & 12 & 12 & 12 & 12 \\
\hline \multirow[t]{3}{*}{ Left testis } & $\begin{array}{l}\text { Absolute } \\
\text { (g) }\end{array}$ & $1.73 \pm 0.157$ & $1.74 \pm 0.124$ & $=1.71 \pm 0.110$ & $1.67 \pm 0.124$ \\
\hline & $\begin{array}{l}\text { Relative } \\
\text { (\%) }\end{array}$ & $\begin{array}{r}0.407 \pm \\
0.0510\end{array}$ & $\begin{array}{r}0.397 \pm \\
0.0260\end{array}$ & $\begin{array}{r}0.394 \pm \\
0.0443\end{array}$ & $\begin{array}{r}0.372 \pm \\
0.0295\end{array}$ \\
\hline & $\mathrm{N}$ & 12 & 12 & 12 & 12 \\
\hline \multirow[t]{3}{*}{ Right epididymis } & $\begin{array}{l}\text { Absolute } \\
\text { (g) }\end{array}$ & $0.66 \pm 0.063$ & $0.69 \pm 0.064$ & $=0.68 \pm 0.064$ & $=0.66 \pm 0.070$ \\
\hline & $\begin{array}{l}\text { Relative } \\
\text { (\%) }\end{array}$ & $\begin{array}{r}0.155 \pm \\
0.0168\end{array}$ & $\begin{array}{r}0.158 \pm \\
0.0164\end{array}$ & $\begin{array}{r}0.156 \pm \\
0.0208\end{array}$ & $\begin{array}{r}0.148 \pm \\
0.0207\end{array}$ \\
\hline & $\mathrm{N}$ & 12 & 12 & 12 & 12 \\
\hline \multirow[t]{3}{*}{ Left epididymis } & $\begin{array}{l}\text { Absolute } \\
\text { (g) }\end{array}$ & $0.67 \pm 0.065$ & $0.68 \pm 0.061$ & $0.66 \pm 0.061$ & $0.65 \pm 0.058$ \\
\hline & $\begin{array}{l}\text { Relative } \\
(\%)\end{array}$ & $\begin{array}{r}0.157 \pm \\
0.0186\end{array}$ & $\begin{array}{r}0.156 \pm \\
0.0141\end{array}$ & $\begin{array}{r}0.152 \pm \\
0.0194\end{array}$ & $\begin{array}{r}0.145 \pm \\
0.0178\end{array}$ \\
\hline & $\mathrm{N}$ & 12 & 12 & 12 & 12 \\
\hline \multirow{3}{*}{$\begin{array}{l}\text { Seminal vesicles } \\
\text { with } \\
\text { coagulating glands }\end{array}$} & $\begin{array}{l}\text { Absolute } \\
\text { (g) }\end{array}$ & $1.68 \pm 0.205$ & $1.65 \pm 0.286$ & $1.68 \pm 0.216$ & $1.69 \pm 0.212$ \\
\hline & $\begin{array}{l}\text { Relative } \\
\text { (\%) }\end{array}$ & $\begin{array}{r}0.396 \pm \\
0.0468\end{array}$ & $\begin{array}{r}0.378 \pm \\
0.0720\end{array}$ & $\begin{array}{r}0.388 \pm \\
0.0569\end{array}$ & $\begin{array}{r}0.377 \pm \\
0.0478\end{array}$ \\
\hline & $\mathrm{N}$ & 12 & 12 & 12 & 12 \\
\hline
\end{tabular}

$(\mathrm{n}=5$ or 12, mean \pm SD)

\section{Table 6}

Absolute and relative organ weights of $\mathrm{CeO}_{2}$ NPs-treated females during the study period 


\begin{tabular}{|c|c|c|c|c|c|}
\hline & & 0 & 100 & 300 & 1000 \\
\hline $\begin{array}{l}\text { Terminal } \\
\text { weight }(\mathrm{g})\end{array}$ & body (g) & $\begin{array}{r}314.5 \pm \\
19.91\end{array}$ & $\begin{array}{r}316.7 \pm \\
24.09\end{array}$ & $\begin{array}{r}311.0 \pm \\
23.68\end{array}$ & $\begin{array}{r}316.8 \pm \\
19.84\end{array}$ \\
\hline \multirow[t]{2}{*}{ Adrenal glands } & $\begin{array}{l}\text { Absolute } \\
\text { (g) }\end{array}$ & $0.08 \pm 0.007$ & $0.07 \pm 0.011$ & $0.08 \pm 0.010$ & $0.08 \pm 0.007$ \\
\hline & $\begin{array}{l}\text { Relative } \\
(\%)\end{array}$ & $\begin{array}{r}0.028 \pm \\
0.0033\end{array}$ & $\begin{array}{r}0.024 \pm \\
0.0029\end{array}$ & $\begin{array}{r}0.027 \pm \\
0.0034\end{array}$ & $\begin{array}{r}0.027 \pm \\
0.0024\end{array}$ \\
\hline \multirow[t]{2}{*}{ Brain } & $\begin{array}{l}\text { Absolute } \\
\text { (g) }\end{array}$ & $1.94 \pm 0.090$ & $1.93 \pm 0.079$ & $2.02 \pm 0.083$ & $1.96 \pm 0.048$ \\
\hline & $\begin{array}{l}\text { Relative } \\
(\%)\end{array}$ & $\begin{array}{r}0.652 \pm \\
0.0356\end{array}$ & $\begin{array}{r}0.650 \pm \\
0.0220\end{array}$ & $\begin{array}{r}0.692 \pm \\
0.0283\end{array}$ & $\begin{array}{r}0.654 \pm \\
0.0298\end{array}$ \\
\hline \multirow[t]{2}{*}{ Heart } & $\begin{array}{l}\text { Absolute } \\
\text { (g) }\end{array}$ & $1.00 \pm 0.064$ & $0.95 \pm 0.037$ & $0.97 \pm 0.071$ & $1.04 \pm 0.063$ \\
\hline & $\begin{array}{l}\text { Relative } \\
(\%)\end{array}$ & $\begin{array}{r}0.334 \pm \\
0.0130\end{array}$ & $\begin{array}{r}0.321 \pm \\
0.0170\end{array}$ & $\begin{array}{r}0.334 \pm \\
0.0262\end{array}$ & $\begin{array}{r}0.346 \pm \\
0.0194\end{array}$ \\
\hline \multirow[t]{2}{*}{ Kidneys } & $\begin{array}{l}\text { Absolute } \\
\text { (g) }\end{array}$ & $2.28 \pm 0.191$ & $2.23 \pm 0.210$ & $2.14 \pm 0.141$ & $2.23 \pm 0.066$ \\
\hline & $\begin{array}{l}\text { Relative } \\
(\%)\end{array}$ & $\begin{array}{r}0.763 \pm \\
0.0282\end{array}$ & $\begin{array}{r}0.750 \pm \\
0.0512\end{array}$ & $\begin{array}{r}0.734 \pm \\
0.0357\end{array}$ & $\begin{array}{r}0.744 \pm \\
0.0273\end{array}$ \\
\hline \multirow[t]{2}{*}{ Liver } & $\begin{array}{l}\text { Absolute } \\
\text { (g) }\end{array}$ & $\begin{array}{r}10.52 \pm \\
1.205\end{array}$ & $\begin{array}{r}10.40 \pm \\
0.865\end{array}$ & $\begin{array}{r}10.19 \pm \\
0.297\end{array}$ & $\begin{array}{r}10.91 \pm \\
0.730\end{array}$ \\
\hline & $\begin{array}{l}\text { Relative } \\
(\%)\end{array}$ & $\begin{array}{r}3.522 \pm \\
0.2660\end{array}$ & $\begin{array}{r}3.503 \pm \\
0.2766\end{array}$ & $\begin{array}{r}3.495 \pm \\
0.1690\end{array}$ & $\begin{array}{r}3.638 \pm \\
0.2589\end{array}$ \\
\hline \multirow[t]{2}{*}{ Pituitary gland } & $\begin{array}{l}\text { Absolute } \\
\text { (g) }\end{array}$ & $0.02 \pm 0.002$ & $0.02 \pm 0.001$ & $0.02 \pm 0.004$ & $0.02 \pm 0.002$ \\
\hline & $\begin{array}{l}\text { Relative } \\
(\%)\end{array}$ & $\begin{array}{r}0.006 \pm \\
0.0006\end{array}$ & $\begin{array}{r}0.006 \pm \\
0.0005\end{array}$ & $\begin{array}{r}0.006 \pm \\
0.0014\end{array}$ & $\begin{array}{r}0.006 \pm \\
0.0004\end{array}$ \\
\hline \multirow[t]{2}{*}{ Spleen } & $\begin{array}{l}\text { Absolute } \\
\text { (g) }\end{array}$ & $0.62 \pm 0.072$ & $0.69 \pm 0.090$ & $0.65 \pm 0.081$ & $0.70 \pm 0.123$ \\
\hline & $\begin{array}{l}\text { Relative } \\
(\%)\end{array}$ & $\begin{array}{r}0.209 \pm \\
0.0205\end{array}$ & $\begin{array}{r}0.231 \pm \\
0.0285\end{array}$ & $\begin{array}{r}0.223 \pm \\
0.0323\end{array}$ & $\begin{array}{r}0.232 \pm \\
0.0429\end{array}$ \\
\hline \multirow[t]{2}{*}{ Thymus } & $\begin{array}{l}\text { Absolute } \\
\text { (g) }\end{array}$ & $0.31 \pm 0.029$ & $0.31 \pm 0.054$ & $0.31 \pm 0.079$ & $0.38 \pm 0.124$ \\
\hline & $\begin{array}{l}\text { Relative } \\
(\%)\end{array}$ & $\begin{array}{r}0.104 \pm \\
0.0134\end{array}$ & $\begin{array}{r}0.104 \pm \\
0.0209\end{array}$ & $\begin{array}{r}0.105 \pm \\
0.0270\end{array}$ & $\begin{array}{r}0.125 \pm \\
0.0407\end{array}$ \\
\hline \multirow[t]{2}{*}{ Lungs } & $\begin{array}{l}\text { Absolute } \\
\text { (g) }\end{array}$ & $1.34 \pm 0.040$ & $1.29 \pm 0.058$ & $1.42 \pm 0.049$ & $1.36 \pm 0.108$ \\
\hline & $\begin{array}{l}\text { Relative } \\
(\%)\end{array}$ & $\begin{array}{r}0.451 \pm \\
0.0129\end{array}$ & $\begin{array}{r}0.435 \pm \\
0.0179\end{array}$ & $\begin{array}{r}0.486 \pm \\
0.0222\end{array}$ & $\begin{array}{r}0.453 \pm \\
0.0339\end{array}$ \\
\hline \multirow[t]{2}{*}{ Uterus } & $\begin{array}{l}\text { Absolute } \\
\text { (g) }\end{array}$ & $0.78 \pm 0.123$ & $0.78 \pm 0.090$ & $0.83 \pm 0.116$ & $0.73 \pm 0.062$ \\
\hline & $\begin{array}{l}\text { Relative } \\
(\%)\end{array}$ & $\begin{array}{r}0.260 \pm \\
0.0387\end{array}$ & $\begin{array}{r}0.262 \pm \\
0.0295\end{array}$ & $\begin{array}{r}0.284 \pm \\
0.0354\end{array}$ & $\begin{array}{r}0.243 \pm \\
0.0262\end{array}$ \\
\hline \multirow[t]{2}{*}{ Right ovary } & $\begin{array}{l}\text { Absolute } \\
\text { (g) }\end{array}$ & $0.07 \pm 0.009$ & $0.06 \pm 0.009$ & $0.06 \pm 0.008$ & $0.06 \pm 0.011$ \\
\hline & $\begin{array}{l}\text { Relative } \\
(\%)\end{array}$ & $\begin{array}{r}0.021 \pm \\
0.0024\end{array}$ & $\begin{array}{r}0.021 \pm \\
0.0037\end{array}$ & $\begin{array}{r}0.019 \pm \\
0.0027\end{array}$ & $\begin{array}{c}0.019 \pm \\
0.0036\end{array}$ \\
\hline
\end{tabular}




\begin{tabular}{llrrrr} 
& & $\mathbf{0}$ & $\mathbf{1 0 0}$ & $\mathbf{3 0 0}$ & $\mathbf{1 0 0 0}$ \\
\cline { 3 - 6 } Left ovary & Absolute & $0.07 \pm 0.019$ & $0.06 \pm 0.005$ & $0.06 \pm 0.012$ & $0.05 \pm 0.007$ \\
$(\mathrm{~g})$ & & & & \\
Relative & $0.023 \pm$ & $0.020 \pm$ & $0.020 \pm$ & $0.018 \pm$ \\
$(\%)$ & 0.0058 & 0.0021 & 0.0046 & 0.0024 \\
\hline
\end{tabular}

$(n=5$, mean $\pm S D)$

\section{Table 7}

Selected histopathological examination results of $\mathrm{CeO}_{2}$ NPs-treated males and females during the study period 


\section{Males}

Adrenal glands

Vacuolation, corticomedullary $\quad$ Grade $10 \quad-\quad$ - 1

Epididymis

Infiltration, mononuclear cell $\quad$ Grade $100 \quad-\quad \begin{array}{llll}1 & 0 & & \end{array}$

Heart

Cardiomyopathy

Grade $13 \quad-\quad-\quad 1$

Jejunum

Mineralization, Peyer's patch

Kidneys

Basophilia, tubules

Casts

Cyst(s)

Dilation, tubules

Infiltration, mononuclear cell

Mineralization

Liver

Infiltration, mononuclear cell

Necrosis, focal

Vacuolated area

Lungs with bronchi

Aggregation, foamy macrophage

Infiltration, inflammatory cell

Osseous metaplasia

Lymph node, mesenteric

Mineralization

Prostate

Infiltration, inflammatory cell

Spleen

Hemopoiesis

Stomach

Dilation, glands

Grade $10 \quad-\quad$ - 1

$\begin{array}{lllll}\text { Grade } 1 & 1 & 3 & 2 & 4\end{array}$

Grade $200 \quad 1 \quad 00$

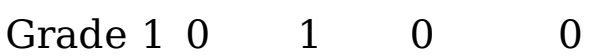

$\begin{array}{lllll}\text { Grade } 1 & 1 & 0 & 0 & 0\end{array}$

Grade $100 \quad 0 \quad 0 \quad 1$

Grade $12 \quad 0 \quad 2 \quad 0$

Grade $100 \quad 0 \quad 1 \quad 0$

Grade 14 - $\quad$ - 0

Grade $11 \quad$ - $\quad$ - 0

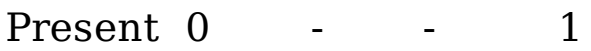

Grade $11 \quad$ - $\quad$ - 2

Grade $11 \quad$ - $\quad$ - 0

Present 1 - $\quad-\quad 0$

Grade 11 - $1 \quad$ - 0

Grade 13 - 3 - 3

Grade $21 \quad$ - 100

Grade 11 - $1 \quad$ - 0

Grade $10 \quad$ - $\quad$ - 1

Testes

Atrophy, tubules

Thyroid and parathyroid glands

Ultimobranchial cyst

Grade 11 - $1 \quad$ - 0

Present $0 \quad-\quad-\quad 2$

\section{Females}

Heart

Cardiomyopathy

Grade 11 - $1 \quad$ - 0

Kidneys

Basophilia, tubules

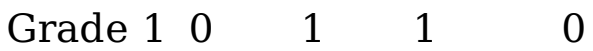

Dilation, tubules

$\begin{array}{lllll}\text { Grade } 1 & 1 & 0 & 1 & 1\end{array}$




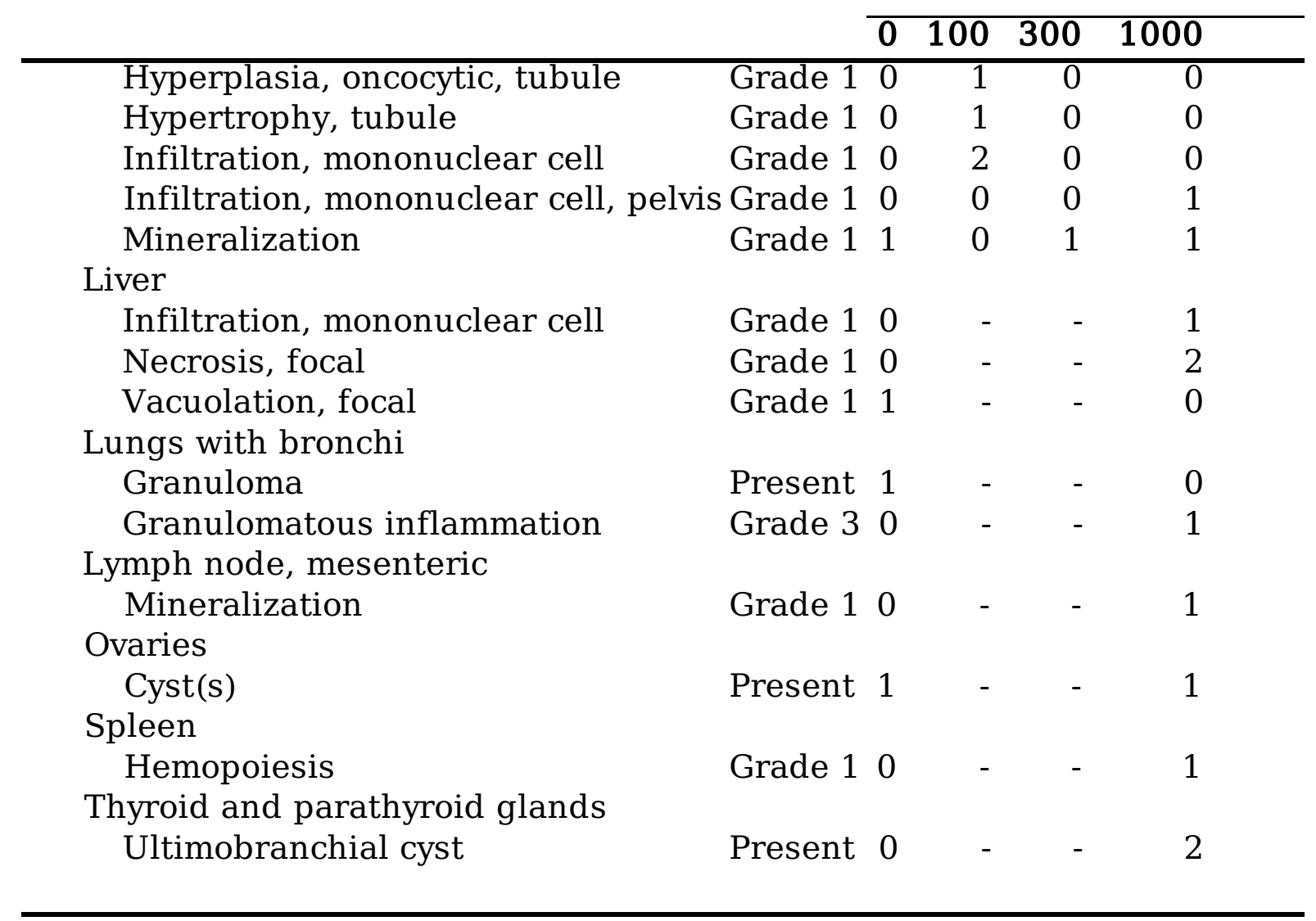

Grades: 1 (minimal), 2 (slight), 3 (moderate), 4 (marked), 5 (severe), -: Not examined, $(n=5)$

\section{Table 8}

Fertility with precoital time results of $\mathrm{CeO}_{2}$ NPs-treated males during the study period 
$\mathrm{CeO}_{2} \mathrm{NPs}(\mathrm{mg} / \mathrm{kg})$

\begin{tabular}{|c|c|c|c|c|}
\hline & 0 & 100 & 300 & 1000 \\
\hline \multicolumn{5}{|l|}{ Males } \\
\hline Mating index $\left.{ }^{a}\right)$ & 100 & 100 & 100 & 100 \\
\hline Fertility index ${ }^{\mathrm{b}}$ & 100 & 100 & 100 & 100 \\
\hline Fecundity index ${ }^{\mathrm{c})}$ & 100 & 100 & 100 & 100 \\
\hline \multicolumn{5}{|l|}{ Females } \\
\hline Mating index ${ }^{\mathrm{d})}$ & 100 & 100 & 100 & 100 \\
\hline Fertility index ${ }^{\mathrm{e})}$ & 100 & 100 & 100 & 100 \\
\hline Pregnancy index ${ }^{\mathrm{f}}$ & 100 & 100 & 100 & 100 \\
\hline Precoital Time (day) & \multicolumn{4}{|c|}{$3.3 \pm 3.581 .8 \pm 0.622 .2 \pm 1.111 .9 \pm 1.08$} \\
\hline
\end{tabular}

a) (No. of males with evidence of mating/No. of males paired) $\times 100$

b) (No. of males impregnating a female/No. of males paired) $\times 100$

c) (No. of males impregnating a female/No. of males with evidence of mating) $\times 100$

d) (No. of females with evidence of mating/No. of females paired) $\times 100$

e) (No. of pregnant females/No. of females paired) $\times 100$

f) (No. of pregnant females/No. of females with evidence of mating) $\times 100$ $(\mathrm{n}=12$, mean $\pm \mathrm{SD})$

\section{Table 9}

Reproductive and littering findings results of $\mathrm{CeO}_{2}$ NPs-treated females during the study period 


\begin{tabular}{llll}
\hline 0 & 100 & 300 & 1000
\end{tabular}

Gestation period (day)

Corpora lutea (day)

Implantations (N)

Pups born (N)

Perinatal death $(\mathrm{N})$

Unaccounted-for sites ${ }^{\text {a) }}(\%)$

Sex ratio ${ }^{\mathrm{b})}(\%)$

Live litter size $(\mathrm{N})$

PND 0

PND 4

Viability index ${ }^{\mathrm{c})}(\%)$

Delivery index ${ }^{\mathrm{d})}(\%)$

Pups with external

$\begin{array}{rrrr}21.5 \pm 0.43 & 21.5 \pm 0.30 & 21.6 \pm 0.31 & 21.8 \pm 0.40 \\ 17.8 \pm 2.76 & 16.5 \pm 2.58 & 16.3 \pm 1.66 & 17.4 \pm 2.02 \\ 15.3 \pm 3.05 & 15.3 \pm 2.42 & 14.8 \pm 2.08 & 15.4 \pm 2.02 \\ 14.8 \pm 3.10 & 14.4 \pm 2.39 & 13.9 \pm 2.02 & 14.8 \pm 2.12 \\ 0.08 \pm 0.29 & 0.00 \pm 0.00 & 0.00 \pm 0.00 & 0.25 \pm 0.45 \\ 2.8 \pm 4.45 & 5.5 \pm 5.82 & 6.2 \pm 4.47 & 3.9 \pm 4.52 \\ 106.9 \pm & 93.9 \pm & 105.3 \pm & 130.7 \pm \\ 62.62 & 28.20 & 55.49 & 66.77\end{array}$

$14.8 \pm 3.0514 .4 \pm 2.39$

$14.8 \pm 3.0514 .3 \pm 2.39$

$13.9 \pm 2.02 \quad 14.6 \pm 2.11$

$13.8 \pm 1.96 \quad 14.4 \pm 1.98$

$100.099 .4 \pm 1.92 \quad 98.9 \pm 2.61 \quad 99.0 \pm 2.39$

$\begin{array}{llll}100.0 & 100.0 & 100.0 & 100.0\end{array}$

0

0

0

0

a) (No. of implantation sites/litter) - (No. of live pups at birth/litter) / No. of implantation sites/litter $\times 100$

b) (No. of male pups on PND 0/litter) / (No. of female pups on PND 0/litter) $\times 100$

c) (No. of live pups on PND 4/litter) / (No. of live pups at birth/litter) $\times 100$

d) (No. of dams with live pups) / (No. of pregnant dams) $\times 100$

$(\mathrm{n}=12$, mean $\pm \mathrm{SD})$

\section{Table 10}

F1 pups body weights of $\mathrm{CeO}_{2}$ NPs-treated parental animals during the study period 


\begin{tabular}{llll}
0 & 100 & 300 & 1000 \\
\hline
\end{tabular}

\section{F1 male pups}

PND 0

Body weight (g)

$6.5 \pm 0.38$

$6.7 \pm 0.33$

$\begin{array}{rr}6.8 \pm 0.59 & 7.0 \pm 0.47 \\ 6.80 & 7.04^{*}\end{array}$

Covariate-adjusted mean (g)

PND 4

6.50

6.67

Body weight (g)

$\begin{array}{cccc}10.1 \pm 0.82 & 10.7 \pm 1.07 & 11.0 \pm 1.14 & 11.0 \pm 1.21 \\ 10.07 & 10.64 & 10.87 & 11.20^{*}\end{array}$

\section{F1 female pups}

PND 0

Body weight $(g)$

Covariate-adjusted mean (g)

PND 4

Body weight (g)

Covariate-adjusted mean (g)
$6.2 \pm 0.41$
6.20
$6.3 \pm 0.29$
6.29
$6.4 \pm 0.55$
6.39
$6.7 \pm 0.56$
6.69*
$9.5 \pm 0.8910 .0 \pm 0.9710 .4 \pm 1.2010 .6 \pm 1.39$
$\begin{array}{llll}9.56 & 10.05 & 10.38 & 10.52\end{array}$

* Represent a significant difference at the $\mathbf{p}<0.05$ level compared to the vehicle control. ( $\mathrm{n}=12$, mean $\pm \mathrm{SD}$ )

\section{Figures}



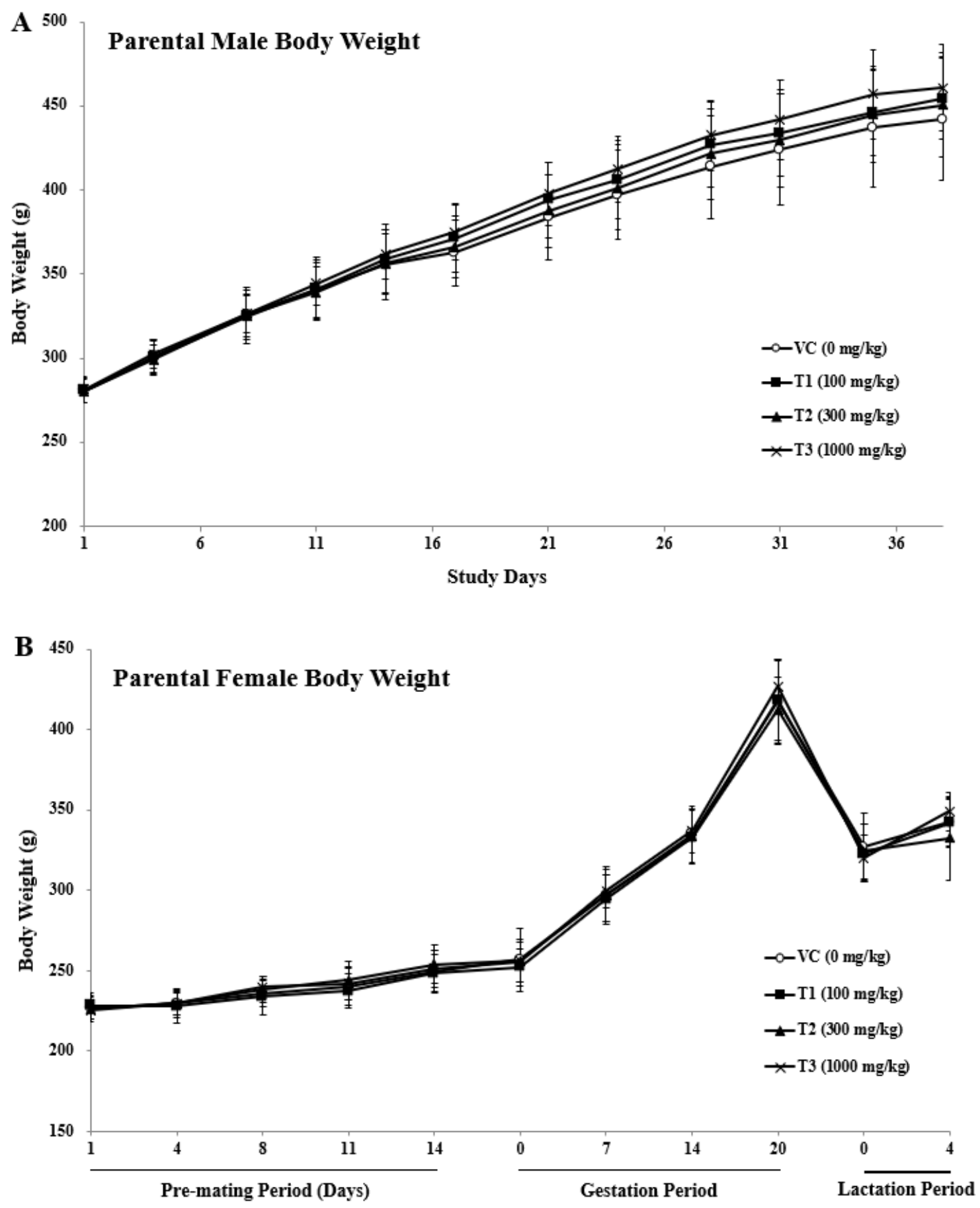

Figure 1

Body weights of CeO2 NPs-treated males (A) and females (B) during the study period ( $n=12$, mean \pm SD)

\section{Supplementary Files}

This is a list of supplementary files associated with this preprint. Click to download. 
- Table1.docx

Page 31/31 